\title{
Less effect of wells physicochemical properties on the antimicrobial susceptibility Pseudomonas aeruginosa isolated in equatorial region of Central Africa
}

\author{
Jean Samuel Eheth ${ }^{1}$. Chrétien Lontsi Djimeli ${ }^{1}$ Paul Alain Nana ${ }^{1}$. Antoine Tamsa Arfao ${ }^{1,2}$. \\ Olive Vivien Noah Ewoti ${ }^{1}$. Luciane Marlyse Moungang ${ }^{1}$ - Geneviève Bricheux ${ }^{3}$ - Télesphore Sime-Ngando ${ }^{3}$. \\ Moïse Nola ${ }^{1}$
}

Received: 13 July 2018 / Accepted: 11 February 2019 / Published online: 23 February 2019

(c) The Author(s) 2019

\begin{abstract}
This study aimed at assessing the impact of some wells abiotic factors on the antimicrobial susceptibility of Pseudomonas aeruginosa isolated. A total of 14 well waters of Douala and Yaoundé towns (Cameroon, Central Africa) were chosen. Fifteen antibiotics were used to test antimicrobial susceptibility with the majority belonging to $\beta$-lactam, aminoglycoside and quinolone groups. Result showed that in Douala, electrical conductivity of water ranged from 145.38 to $559.69 \mu \mathrm{S} / \mathrm{cm}$ in well, while in Yaoundé, it ranged from 172.5 to $710.2 \mu \mathrm{S} / \mathrm{cm}$. Dissolved oxygen ranged from 2.5 to $5.5 \mathrm{mg} / \mathrm{l}$ and from 3.9 to $5.1 \mathrm{mg} / \mathrm{l}$, respectively, in Douala and Yaoundé. Organic matter varied from 2.3 to $7.2 \mathrm{mg} / \mathrm{l}$ and 1.4 to $5.2 \mathrm{mg} / \mathrm{l}$ in Douala and Yaoundé, respectively. As for pH, it fluctuated between 5.56 and $6.66 \mathrm{CU}$ and between 5.1 and 7.0, respectively, in Douala and Yaoundé. The sampled waters harbour multi-drug-resistant $P$. aeruginosa strains. About $20.40 \%$ of strains from wells in Yaoundé metropolis expressed resistance to at least 5 antibiotics, whereas from wells in Douala town, up to 33.33\% of strains were resistant to at least 8 antibiotics including ticarcillin, ceftazidime and gentamicin. The effect of abiotic factors on the sensitivity to antibiotics was assessed using the multiple regression tests. In both towns, less than $5 \%$ in the changes of physicochemical parameters of well waters explained the variance in inhibition diameter values of antibiotics $(p \leq 0.05)$. The $\mathrm{pH}$ significantly impacts on antimicrobial susceptibility. Environmental conditions are less stressful for $P$. aeruginosa and fairly affect its antimicrobial susceptibility.
\end{abstract}

Keywords Wells $\cdot$ P. aeruginosa $\cdot$ Antimicrobial susceptibility $\cdot$ Abiotic factors

\section{Introduction}

Pseudomonas aeruginosa is a Gram-negative bacterium implicated in cutaneous and ophthalmic infections, gastrointestinal attacks leading sometimes to diarrhoeic in newborns. In most cases, these infections are associated with

Moïse Nola

moise.nola@yahoo.com

1 Hydrobiology and Environment Laboratory, Faculty of Sciences, University of Yaounde 1, P.O. Box 812, Yaounde, Cameroon

2 Microbiology and Biotechnology Laboratory, Saint Jerome Catholic University of Douala, P.O. Box 5949, Douala, Cameroon

3 Laboratoire 'Microorganismes: Génome et Environnement', UMR CNRS 6023, Université Clermont Auvergne, Campus Universitaire des Cézeaux, 1 Impasse Amélie Murat CS 60026, 63178 Aubière Cedex, France contaminated water or contaminated antiseptic solutions (Mérens et al. 2013). Infections caused by $P$. aeruginosa are sometime difficult to treat because of its high level of intrinsic resistance to antibiotics (Hancock and Speert 2000). This opportunist bacterium can also exhibit high adaptive response to changing environmental conditions (Mérens et al. 2011). In developing countries where access to potable water and sanitation is limited, the presence of this resistant bacterium in aquatic environments is a serious public health threat (Satoru and Phan 2012). 
Antimicrobial susceptibility must not be considered just as a medical issue but also as an ecological matter. To understand the process by which antimicrobial susceptibility is governed in environmental bacteria, it is necessary to consider the ecology of microorganisms as well as the potential impact of environmental conditions (Macfarlane et al. 2000). Just like many microorganisms, $P$. aeruginosa is frequently exposed to environmental stresses such as UV radiation, acid stress $(\mathrm{pH})$, nutrient starvation and oxygen limitation related to organic pollution (Poole 2012a). These stresses elicit a variety of specific and highly regulated adaptive responses that not only protect the bacterium from the offending stress, but also alter gene expression patterns (Wood and Ohman 2009) and cell physiology in ways that it can profoundly influence antimicrobial susceptibility (Macdonald and Kuehn 2013). According to Poole (2012b), the physiological changes in a bacterium exposed to environmental stresses are often transient but occasionally permanent depending on the adaptive changes in the genetic architecture of the microorganism. McMahon et al. (2007) added that some pathogens continued to express higher levels of antibiotic resistance after removal of stress, suggesting that in some cases sublethal stress may induce stable increases in antibiotic resistance.

In Cameroon, data on the antimicrobial susceptibility of bacteria originated from aquatic environments are very fragmentary (Akoachere et al. 2013). Investigations on drug resistance are mostly performed with clinical strains because of their implication in nosocomial infections (Ateba et al. 2013; Kamga et al. 2015). Yet the presence of resistant bacteria in aquatic ecosystems increases the risks during infection by water since the therapeutic possibilities are reduced. In urban areas such as Douala and Yaoundé, populations depend mainly on groundwaters which are consumed sometimes without efficient treatment (Drouart and Vouillamoz 2012; INS 2013). These groundwaters harbour diverse bacterial microflora primarily consisting of faecal bacteria, which are commensal or pathogenic (Nola et al. 2001; Nougang et al. 2011). The opportunist bacterium $P$. aeruginosa isolated from wells of Douala often expressed acquired resistances against several antibiotics such as doxycycline, cotrimoxazole, tetracycline and ampicillin (Akoachere et al. 2013). Otherwise, groundwaters of Douala and Yaoundé are acidic with low dissolved oxygen and nutrients contents (Nola et al. 2001; Nougang et al. 2011). These conditions are potentially stressful for the local bacterial microflora. The impact of these environmental conditions on the occurrence of resistant $P$. aeruginosa strains has not been yet undertaken. Although the reasons and the factors of the resistances remain poorly documented in natural water, it is well known that increasing resistance in aquatic environments in urban areas is mainly assigned to anthropogenic pollution. The implication of some anthropogenic ecosystems (hospital effluents, wastewater treatment stations, farms) in the dissemination of the resistance has been demonstrated through several works which characterized these ecosystems as reservoirs of multi-drug resistant bacteria, resistance genes and mobile genetic elements, but also as the platforms of genetic exchanges between bacterial species (Czekalski et al. 2012; Fuentefria et al. 2011; Gaze et al. 2011). However, little is known about the possible impact of physicochemical characteristics of water on the occurrence of multi-drug-resistant $P$. aeruginosa strains in these environments. The aim of this study was to have firsthand information about the possible relationship between water pollution and the antimicrobial susceptibility of $P$. aeruginosa strains in two urban areas.

\section{Materials and methods}

\section{Site description}

Douala town is located between $3^{\circ} 5^{\prime}$ and $4^{\circ} 15^{\prime}$ at latitude North and between $9^{\circ} 37^{\prime}$ and $9^{\circ} 50^{\prime}$ at longitude East, along the coastal plain of Cameroon. The relief is made of sedimentary formations (clays, marls, sands, sandstone, etc.) and an important proportion of hydromorphic soils (Hieng 2003). The population of this city is more of 2,000,000 inhabitants (BUCREP 2010). Several investigations showed that $2 / 3$ of the population do not have access to the network water and rely on boring, wells and natural springs. The water quality of $3 / 4$ of borings and wells is uncertain because of the proximity of the groundwater table and the sandy geologic plinth which favour the circulation of contaminants (Drouart and Vouillamoz 2012).

Yaoundé City is located between latitude $3^{\circ} 44^{\prime}$ and $4^{\circ} 2^{\prime}$ North and longitude $11^{\circ} 22^{\prime}$ and $11^{\circ} 24^{\prime}$ East. It has ferrolateritic acidic soils with clayed texture (Hieng 2003). The demography of Yaoundé is of about 2,000,000 inhabitants (BUCREP 2010). Groundwaters play a fundamental role in the water supply in Yaoundé, where less than 50\% of households have direct access to the drinking water delivered through pipeline (INS 2013). Studies established that groundwater pollution comes mainly from traditional pit latrines and agricultural activities. 53\% of households are exposed to waterborne diseases by consuming groundwaters (INS 2013).

\section{Water sampling}

In each study area, 14 dug wells, coded WY1, WY2, ......,WY14 in Yaoundé, and WD1, WD2, .....WD14 in Douala, were selected according to their accessibility and their spatial distribution. Water samplings were done from April 2013 to April 2014 in order to explore environmental conditions leading in groundwaters during all seasons of the 
year. Water samples from the 14 wells of each town were collected and analysed monthly. At each sampling point, two water samples were collected, one in a 500-ml sterile glass bottle for bacteriological analysis and the other in a 1000-ml polythene bottle for organic matter analysis.

\section{Analyses of water physicochemical parameters}

At each sampling site, the water $\mathrm{pH}$, dissolved oxygen and electrical conductivity were determined in situ (using a multi-parameter analyser kit HANNA Instruments) to estimate their impact on antimicrobial susceptibility. Organic matter (chemical oxygen demand) was evaluated in laboratory by the chromic acid wet digestion titrimetric method. These parameters were chosen since they are indicators of the organic pollution. Physicochemical analyses were made according to Rodier (2009) and APHA (2012).

\section{Bacterial isolation and identification}

Membrane filtration method was used to isolate and enumerate $P$. aeruginosa cells according to the standard methods (APHA 2012). For each well, raw or diluted water sample was filtered through a sterile $0.45-\mu \mathrm{m}$-pore-diameter, gridded membrane filter, under partial vacuum. Filter was removed and placed on cetrimide-nalidixic agar culture medium (CN, Difco Laboratories, Detroit, MI, USA) contained in Petri dish (Gosselin a Corning Brand, France). Incubation was done at $37{ }^{\circ} \mathrm{C}$ for $24 \mathrm{~h}$. The typical $P$. aeruginosa colonies on $\mathrm{CN}$ agar medium were subsequently identified according to Holt et al. (2000) and confirmed using King B medium, acetamide and oxydase tests (Goto and Enomoto 1970).

\section{Antimicrobial susceptibility tests}

The antimicrobial susceptibility tests were carried out using Kirby-Bauer disc diffusion method as indicated by CA-SFM (2013). Three hundred and eleven and 312 P. aeruginosa strains were, respectively, collected in wells of Douala and Yaoundé. Fifteen antibiotics were tested belonging to 4 groups (CA-SFM 2013): $\beta$-lactam, aminoglycoside, quinolone and one non-classified group. The $\beta$-lactam group included piperacillin $(75 \mu \mathrm{g})$, piperacillin/tazobactam $(75 / 10 \mu \mathrm{g})$, ticarcillin $(75 \mu \mathrm{g})$, ticarcillin/clavulanate $(75 / 10 \mu \mathrm{g})$, ceftazidime $(30 \mu \mathrm{g})$, cefepime $(30 \mu \mathrm{g})$, cefsulodin $(30 \mu \mathrm{g})$, imipenem $(10 \mu \mathrm{g})$ and meropenem $(10 \mu \mathrm{g})$. The aminoglycoside included tobramycin $(10 \mu \mathrm{g})$, gentamicin $(15 \mu \mathrm{g})$ and amikacin $(30 \mu \mathrm{g})$. The quinolones used were ciprofloxacin $(5 \mu \mathrm{g})$ and ofloxacin $(5 \mu \mathrm{g})$. The non-classified antibiotic was fosfomycin (50 $\mu \mathrm{g}+50 \mu \mathrm{g}$ G6P).

Pseudomonas aeruginosa strain ATCC 27853 susceptibility was used as control. This strain was provided by the
Laboratory of Microbiology and Environment of Centre Pasteur of Cameroon. Test results were only validated in the cases where inhibition zone diameters of the control strains were within performance ranges. Inhibition zone diameters of $P$. aeruginosa isolates were measured and then compared with the reference data (CA-SFM) to assess if strains were resistant $(\mathbf{R})$, intermediate (I) or sensitive (S) to the tested antibiotics.

\section{Data analysis}

Prevalence of resistant $(\mathbf{R})$, intermediate $(\mathbf{I})$ or sensitive $(\mathbf{S})$ strains to each antibiotic was plotted using SigmaPlot 10.0 software. To assess a dimensional measurement of the linear relationship between the inhibition diameter values of each antibiotic and physicochemical parameter of well waters, multiple regressions were done using the software XLSTAT 2007. The regression equation model defined was: $Y=a_{0}+$ $a_{1} \mathrm{EC}+a_{2} \mathrm{pH}+a_{3} \mathrm{DO}+a_{4} \mathrm{OM}$. Y (inhibition diameter value of antibiotic) was assigned to the depended variable. The explanatory variables were EC (electrical conductivity), $\mathrm{pH}$, DO (dissolved oxygen) and OM (organic matter). The slopes parameters $a_{1}, a_{2}, a_{3}$ and $a_{4}$ showed how $\mathrm{Y}$ changes with one unit of corresponding physicochemical parameter. $a_{0}$ represented the intercept point. $R^{2}$ values were determined to measure the percentage of variation in the values of inhibition diameter of antibiotics that can be explained by the variation in the explanatory variables. A $p$ value of 0.05 was assumed to be statistical significance level.

\section{Results}

\section{Wells physicochemical characteristics}

In Douala metropolis, the mean values of physicochemical parameters measured in the wells varied with respect to the sampling site (Table 1). The electrical conductivity values ranged from 145.38 to $559.69 \mu \mathrm{S} / \mathrm{cm}$, meaning that mineralization rate of these waters was average (Rodier 2009). The $\mathrm{pH}$ values fluctuated between 5.56 and 6.66 and revealed acidic groundwaters. Dissolved oxygen concentration ranged from 2.5 to $5.5 \mathrm{mg} / \mathrm{l}$, and concentrations in organic matter varied from 2.3 to $7.2 \mathrm{mg} / \mathrm{l}$.

In Yaoundé, the value of physicochemical parameters measured in wells also varied with respect to sampling site (Table 2). The highest value of electrical conductivity reached $710.2 \mu \mathrm{S} / \mathrm{cm}$, and the lowest value reached 172.5 $\mu \mathrm{S} / \mathrm{cm}$. The observed difference in electrical conductivity may be due to the local source of pollution. Well waters were slightly acidic with $\mathrm{pH}$ ranging from 5.1 to 7.0. Dissolved oxygen levels ranged from 3.9 to $5.1 \mathrm{mg} / \mathrm{l}$, and the concentration in organic matter varied from 1.4 to $5.2 \mathrm{mg} / \mathrm{l}$. 


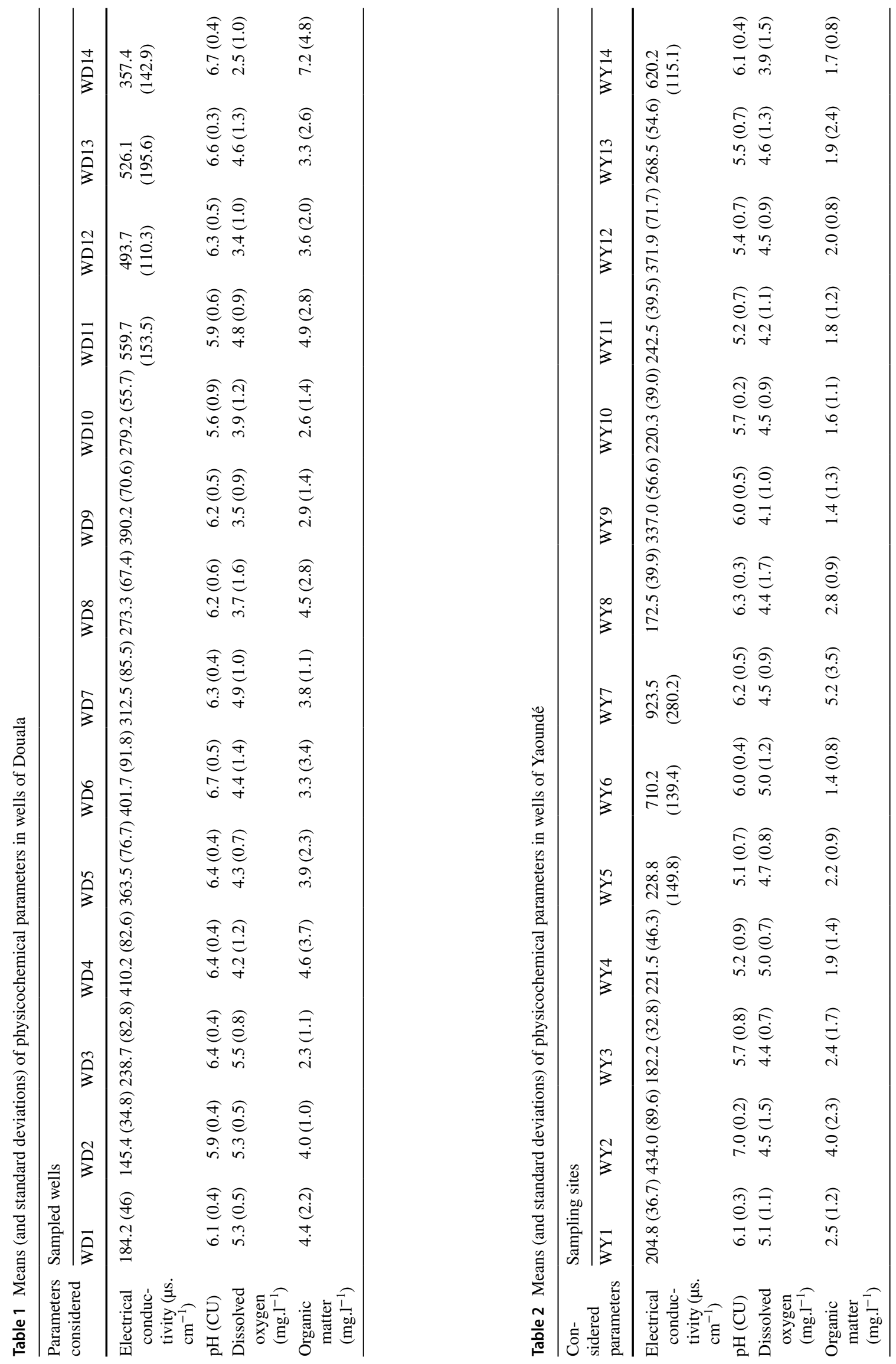




\section{Antimicrobial susceptibility patterns among $P$. aeruginosa strains and multiresistance aspect}

A total of $623 P$. aeruginosa strains were collected and tested. Out of this number, 311 and 312 strains were collected, respectively, from wells in Douala and Yaoundé. The prevalence of the resistant, intermediate and sensitive strains isolated is illustrated in Fig. 1.

In groundwaters of Yaoundé, $P$. aeruginosa strains expressed highest resistance to fosfomycin $(90.09 \%)$ and ofloxacin $(30 \%)$ and lowest resistance to tobramycin $(0.6 \%)$ (Fig. 1a). In well waters of Douala, $P$. aeruginosa strains expressed highest resistance rates to fosfomycin (77.88\%) and lowest resistance to cefsulodin (2.88\%) (Fig. 1b). The prevalence of resistant strains to ceftazidime, ticarcillin, gentamicin, tobramycin and amikacin was relatively different in wells of Douala when compared to those of Yaoundé (Fig. 1). Resistant strains to cefsulodin were recorded in wells of Douala (2.88\%), while in Yaoundé there were no resistant strains recorded to this drug.

In wells of both towns, the most active antibiotics against $P$. aeruginosa strains were ciprofloxacin, colistin, meropenem, imipenem and piperacillin/tazobactam (Fig. 1). The resistance level to combined antibiotics piperacillin/tazobactam and ticarcillin/clavulanate was different in Yaoundé and Douala (Fig. 1). About $17.16 \%$ of strains in Yaoundé town and $6.41 \%$ of strains in Douala town were sensitive to piperacillin/tazobactam but resistant to piperacillin alone. This is not surprising since tazobactam acts as a $\beta$-lactamase inhibitor. About $10.89 \%$ of $P$. aeruginosa strains from wells of Yaoundé and 9.29\% from those in Douala were resistant to antibiotic combination ticarcillin/clavulanate but sensitive to ticarcillin alone.

Figure 2 shows the prevalence of multi-drug-resistant strains. In wells of Yaoundé, about $93.39 \%$ of $P$. aeruginosa strains were resistant to at least 3 antibiotics. The resistance prevalence to at least 4 antibiotics reached $52.14 \%$. Up to $20.46 \%$ of $P$. aeruginosa strains were resistant to at least 5 antibiotics. It has been found that $0.66 \%$ of $P$. aeruginosa strains were resistant to at least 9 antibiotics. In wells of Douala, $85.26 \%$ of $P$. aeruginosa strains expressed resistance to at least 3 drugs (Fig. 2). The prevalence of resistant strains to at least 4 antimicrobials reached $68.58 \%$. Up to $52.24 \%$ of strains were resistant to at least 5 antibiotics. It
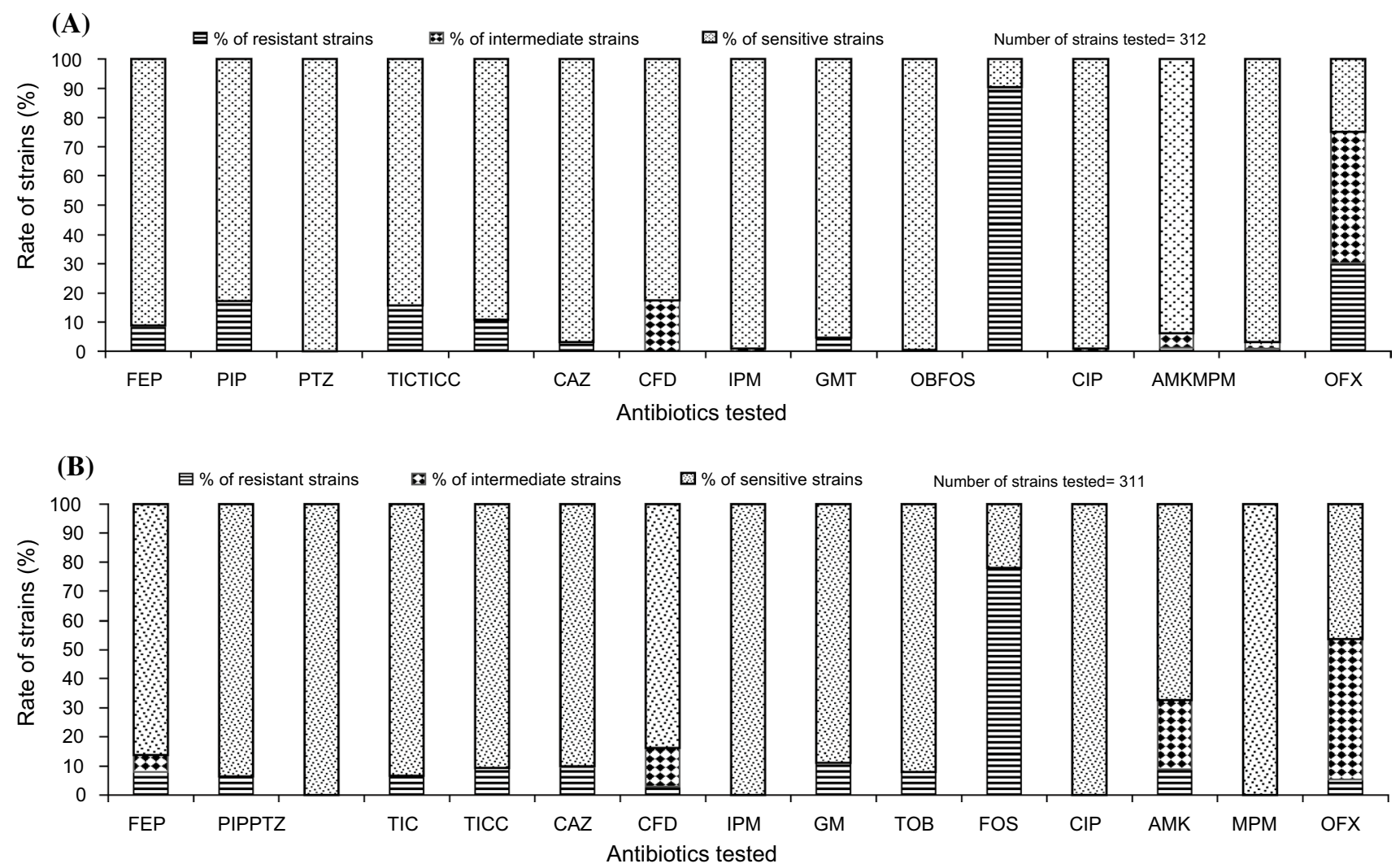

Fig. 1 Antimicrobial susceptibility patterns among P. aeruginosa strains isolated from wells in Yaoundé of clayey lateritic soil (a), and in Douala of sandy soil (b) (FEP cefepime, PIP piperacillin, PTZ piperacillin/tazobactam, CTX cefotaxime, TIC ticarcillin, TICC ticar- cillin/clavulanate, $C A Z$ ceftazidime, $C F D$ cefsulodin, $I M P$ imipenem, $G M$ gentamicin, TOB tobramycin, AZT aztreonam, FOS fosfomycin, $C O L$ colistin, $C I P$ ciprofloxacin, $A M K$ amikacin, $K M C$ kanamycin, $M P M$ meropenem, $O F X$ ofloxacin) 


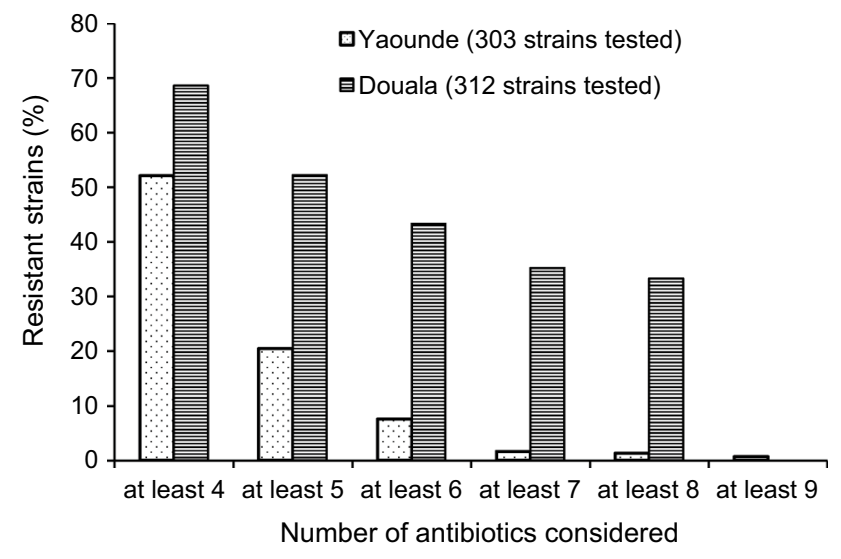

Fig. 2 Variation of the percentage of multi-drug-resistant P. aeruginosa isolates with the number of antibiotics they resist to and the isolation sites (Yaoundé and Douala)

is noted that up to $33.33 \%$ of strains expressed multi-drug resistance to at least 8 antibiotics.

\section{Impact of physicochemical parameters of water on the antibiotics sensitivity of Pseudomonas aeruginosa}

The effect of physicochemical water parameters on the inhibition diameter of $P$. aeruginosa was assessed using the multiple regression test, and the results are presented in Tables 3 and 4.
With strains isolated from wells in Yaoundé, the percentage of variation in the values of inhibition diameters of antibiotics that can be explained by the variation in the physicochemical parameters of wells oscillated between 0.7 and $4.1 \%(p \leq 0.05)$. The lowest $R^{2}$ values were observed with ofloxacin, meropenem, amikacin, imipenem and ceftazidime. The regression equation which showed the highest $R^{2}$ values was obtained with ticarcillin (Table 3 ). When examining specific slopes assigned to each physicochemical parameter, the $\mathrm{pH}$ of well waters seems to be the abiotic factor having the steepest slopes ranging from 0.4 to 1.8 (Table 3). These slopes showed how inhibition diameter of antibiotics changes with $\mathrm{pH}$. The slopes of electrical conductivity varied between 0.00005 and 0.002 , while those of dissolved oxygen oscillated between 0.006 and 0.4 . The slopes assigned to the organic matter ranged from 0.01 to $0.3(p \leq 0.05)$.

With $P$. aeruginosa strains isolated from well in Douala town, $2.5 \%$ to $4.8 \%$ of the variance in inhibition diameter values of antibiotics can be explained by the changes in physicochemical parameters (Table 4 ). The lowest $R^{2}$ value was observed with ofloxacin and fosfomycin, while the highest $R^{2}$ value was obtained with ceftazidime. The slopes attributed to each abiotic factor ranged from 0.1 to 4.8 with the $\mathrm{pH}$, from 0.002 to 0.005 with the electrical conductivity, from 0.3 to 0.5 with the dissolved oxygen and from 0.003 to 0.2 with the organic matter.

In both towns, less than $5 \%$ of the changes in physicochemical parameters of well waters explained the variance in inhibition diameter values of antibiotics $(p \leq 0.05)$. The
Table 3 Multiple regression of inhibition diameter values of antibiotics with abiotic factors in wells of Yaoundé

\begin{tabular}{lll}
\hline $\begin{array}{l}\text { Depended variables (inhibition diam- } \\
\text { eters of antibiotic tested) }\end{array}$ & Regression equation & $R^{2}$ value \\
\hline $\mathrm{FEP}=$ & $27-0.002 \mathrm{EC}-1.4 \mathrm{pH}-0.2 \mathrm{DO}-0.1 \mathrm{OM}$ & 0.014 \\
$\mathrm{PIP}=$ & $27-0.001 \mathrm{EC}-1.4 \mathrm{pH}-0.2 \mathrm{DO}-0.3 \mathrm{OM}$ & 0.014 \\
$\mathrm{PTZ}=$ & $25-0.003 \mathrm{EC}-0.7 \mathrm{pH}-0.004 \mathrm{DO}-0.04 \mathrm{OM}$ & 0.011 \\
$\mathrm{TIC}=$ & $21-0.0008 \mathrm{EC}-1.1 \mathrm{pH}-0.006 \mathrm{DO}-0.2 \mathrm{OM}$ & 0.041 \\
$\mathrm{TICC}=$ & $21-0.00005 \mathrm{EC}-1.1 \mathrm{pH}+0.2 \mathrm{DO}-0.08 \mathrm{OM}$ & 0.009 \\
$\mathrm{CAZ}=$ & $27+0.0004 \mathrm{EC}-1.5 \mathrm{pH}-0.1 \mathrm{DO}-0.04 \mathrm{OM}$ & 0.007 \\
$\mathrm{CFD}=$ & $26+0.0008 \mathrm{EC}-1.6 \mathrm{pH}+0.01 \mathrm{DO}-0.02 \mathrm{OM}$ & 0.010 \\
$\mathrm{IMP}=$ & $27-0.0001 \mathrm{EC}-1.3 \mathrm{pH}-0.4 \mathrm{DO}+0.04 \mathrm{OM}$ & 0.007 \\
$\mathrm{GM}=$ & $22-0.0003 \mathrm{EC}-1.3 \mathrm{pH}-0.05 \mathrm{DO}+0.06 \mathrm{OM}$ & 0.010 \\
$\mathrm{TOB}=$ & $20-0.0001 \mathrm{EC}-1.2 \mathrm{pH}+0.01 \mathrm{DO}+0.04 \mathrm{OM}$ & 0.008 \\
$\mathrm{FOS}=$ & $7.6-0.0007 \mathrm{EC}-0.8 \mathrm{pH}+0.07 \mathrm{DO}-0.1 \mathrm{OM}$ & 0.009 \\
$\mathrm{CIP}=$ & $33-0.001 \mathrm{EC}-1.8 \mathrm{pH}-0.1 \mathrm{DO}-0.07 \mathrm{OM}$ & 0.009 \\
$\mathrm{AMK}=$ & $22+0.0002 \mathrm{EC}-1.2 \mathrm{pH}+0.02 \mathrm{DO}-0.01 \mathrm{OM}$ & 0.007 \\
$\mathrm{MPM}=$ & $31-0.001 \mathrm{EC}-1.4 \mathrm{pH}-0.3 \mathrm{DO}-0.04 \mathrm{OM}$ & 0.007 \\
$\mathrm{OFX}=$ & $23-0.001 \mathrm{EC}-1.07 \mathrm{pH}-0.1 \mathrm{DO}+0.05 \mathrm{OM}$ & 0.007 \\
\hline
\end{tabular}

Observations $=182 ; p \leq 0.05$. FEP cefepime, $P I P$ piperacillin, $T I C$ ticarcillin, $T I C C$ ticarcillin/clavulanate, $C A Z$ ceftazidime, $C F D$ cefsulodin, IMP imipenem, $G M$ gentamicin, TOB tobramycin, FOS fosfomycin, $C I P$ ciprofloxacin, $A M K$ amikacin, $M P M$ meropenem, $O F X$ ofloxacin, $E C$ electrical conductivity, $D O$ dissolved oxygen, $O M$ organic matter 
Table 4 Multiple regression of inhibition diameter values of antibiotics with abiotic factors in wells of Douala

\begin{tabular}{llc}
\hline $\begin{array}{l}\text { Depended variables (inhibition diam- } \\
\text { eters of antibiotic tested) }\end{array}$ & Regression equation & $R^{2}$ value \\
\hline $\mathrm{FEP}=$ & $40+0.005 \mathrm{EC}-3.7 \mathrm{pH}+0.4 \mathrm{DO}-0.1 \mathrm{OM}$ & 0.043 \\
$\mathrm{PIP}=$ & $41+0.003 \mathrm{EC}-3.6 \mathrm{pH}+0.4 \mathrm{DO}+0.003 \mathrm{OM}$ & 0.031 \\
$\mathrm{PTZ}=$ & $38+0.004 \mathrm{EC}-3.2 \mathrm{pH}+0.3 \mathrm{DO}+0.03 \mathrm{OM}$ & 0.032 \\
$\mathrm{TIC}=$ & $36+0.003 \mathrm{EC}-3.4 \mathrm{pH}+0.4 \mathrm{DO}-0.005 \mathrm{OM}$ & 0.041 \\
$\mathrm{TICC}=$ & $31+0.003 \mathrm{EC}-2.8 \mathrm{pH}+0.3 \mathrm{DO}-0.02 \mathrm{OM}$ & 0.036 \\
$\mathrm{CAZ}=$ & $43+0.005 \mathrm{EC}-4.1 \mathrm{pH}+0.3 \mathrm{DO}-0.2 \mathrm{OM}$ & 0.048 \\
$\mathrm{CFD}=$ & $39+0.005 \mathrm{EC}-3.5 \mathrm{pH}+0.3 \mathrm{DO}-0.07 \mathrm{OM}$ & 0.035 \\
$\mathrm{IMP}=$ & $41+0.003 \mathrm{EC}-3.7 \mathrm{pH}+0.5 \mathrm{DO}-0.1 \mathrm{OM}$ & 0.038 \\
$\mathrm{GM}=$ & $26+0.002 \mathrm{EC}-2.4 \mathrm{pH}+0.4 \mathrm{DO}+0.01 \mathrm{OM}$ & 0.034 \\
$\mathrm{TOB}=$ & $27+0.002 \mathrm{EC}-2.4 \mathrm{pH}+0.3 \mathrm{DO}+0.008 \mathrm{OM}$ & 0.031 \\
$\mathrm{FOS}=$ & $4.8+0.003 \mathrm{EC}-0.1 \mathrm{pH}+0.6 \mathrm{DO}-0.06 \mathrm{OM}$ & 0.025 \\
$\mathrm{CIP}=$ & $53+0.004 \mathrm{EC}-4.8 \mathrm{pH}+0.5 \mathrm{DO}-0.03 \mathrm{OM}$ & 0.037 \\
$\mathrm{AMK}=$ & $25+0.003 \mathrm{EC}-2.3 \mathrm{pH}+0.6 \mathrm{DO}+0.05 \mathrm{OM}$ & 0.037 \\
$\mathrm{MPM}=$ & $54+0.003 \mathrm{EC}-4.7 \mathrm{pH}+0.3 \mathrm{DO}-0.07 \mathrm{OM}$ & 0.034 \\
$\mathrm{OFX}=$ & $33+0.003 \mathrm{EC}-2.8 \mathrm{pH}+0.3 \mathrm{DO}-0.07 \mathrm{OM}$ & 0.025 \\
\hline
\end{tabular}

Observations $=182 ; p \leq 0.05 . F E P$ cefepime, $P I P$ piperacillin, $T I C$ ticarcillin, $T I C C$ ticarcillin/clavulanate, $C A Z$ ceftazidime, $C F D$ cefsulodin, IMP imipenem, $G M$ gentamicin, TOB tobramycin, $F O S$ fosfomycin, $C I P$ ciprofloxacin, $A M K$ amikacin, $M P M$ meropenem, $O F X$ ofloxacin, $E C$ electrical conductivity, $D O$ dissolved oxygen, $O M$ organic matter
$\mathrm{pH}$ of water seems to be the parameter susceptible to impact the variation in the inhibition diameters values regarding the slopes of regression equations. The slopes values of $\mathrm{pH}$ were relatively more important with strain isolated in Douala than to those isolated in Yaoundé.

\section{Discussion}

Pseudomonas aeruginosa strains isolated from groundwaters of Yaoundé and Douala (tropical regions) were multi-drug resistant. The observed acquired resistance against ticarcillin and ceftazidime is alarming since these antibiotics are recognized to kill $P$. aeruginosa cells and they are preferentially used in hospital against $P$. aeruginosa infections (Kamga et al. 2015). The occurrence of multi-drug-resistant strains in these aquatic ecosystems has been long time questioned. During this study, the measurement of the physicochemical parameters of groundwaters showed that the concentrations of dissolved oxygen corresponded to the normal oxygenated conditions non-stressful for $P$. aeruginosa. The multiple regression tests revealed that the percentage of variation in the values of inhibition diameters of antibiotics tested can be explained by the variation in the physicochemical parameters ranging from 0.7 to $4.1 \%(p \leq 0.05)$ in Yaoundé and from 2.5 to $4.8 \%$ in Douala. These results mean that the relationship between antimicrobial susceptibility of $P$. aeruginos $a$ and abiotic factors would be minimal in both regions. The reasons of this weak relation would be explained by the order of magnitude of the measured physicochemical parameters in groundwaters. Indeed, it has been established that stress is the major environmental parameter that significantly affects $P$. aeruginosa.

Stress selects in bacterium several molecular adaptation mechanisms also involved in antibiotic resistance (Macfarlane et al. 2000; Johnson et al. 2012). However, when the level of physicochemical parameter is not sufficient to induce bacterial stress, its impact on antimicrobial susceptibility would be minimal. According to Ghotaslou and Behnaz (2013), oxygen depletion of 0 to $1 \%(<3 \mathrm{mg} / \mathrm{l})$ could lead to stress in $P$. aeruginosa affecting its antibiotics sensitivity. These authors revealed that changes in oxygen pressure contributed to increased antibiotic resistance in hypoxia $(1 \%)$ with penicillin, tobramycin and carbapenem drugs, while the inhibition diameter values in normoxia $21 \%(5-7 \mathrm{mg} / \mathrm{l})$ remained unchanged. During the sampling campaign, the concentrations of dissolved organic matters obtained were different to those of oligotrophic groundwaters $(<1 \mathrm{mg} / \mathrm{l})$ where organic nutrient limitation leads to nutrient stress against bacteria. According to Nguyen et al. (2011), organic nutrient limitation impacts antimicrobial resistance as a result of its activation of stress responses that promote resistance to gentamicin, meropenem and ofloxacin by activating the stringent response. Groundwaters of these two towns seem to be sufficiently charged in dissolved organic matter, and this environmental condition significantly reduces the impact of nutrient stress against $P$. aeruginosa.

Moreover, intrinsic factors linked to $P$. aeruginosa species might explain weak relation between abiotic factors of well waters and antimicrobial susceptibility. Sequencing

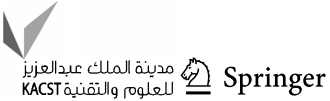


of several $P$. aeruginosa strains genomes revealed that a large fraction (around 10\%) of the genome is dedicated to gene regulation, which is consistent with its high versatility (Mathee et al. 2008; Stover et al. 2000). It has a disparate variety of metabolism; it can degrade very distinct compounds such as alcohols, fatty acids, sugars, di- and tri-carboxylic acids, aromatics, amines and amino acids, which can be used up as sources of carbon. $P$. aeruginosa has both aerobic and anaerobic metabolism. It is capable of anaerobic metabolism by converting nitrate to nitrite. This highest versatility might significantly contribute to escape $P$. aeruginosa from the stress provided by nonoptimal environmental conditions (Schreiber et al. 2007).

The analysis of slopes parameters permitted to appreciate the impact of individual abiotic factors on antimicrobial susceptibility. In both towns, significant slopes $(p \leq 0.05)$ were obtained only with $\mathrm{pH}$. The values of $\mathrm{pH}$ ranged from 5.56 to 6.66 in groundwaters of Douala and from 5.1 to 7.0 in groundwaters of Yaoundé. These values were susceptible to lead to acidic stress and to affect antimicrobial susceptibility of $P$. aeruginosa. Several studies showed that the membrane transport of antibiotics such as aminoglycosides is a function of the difference transmembrane in $\mathrm{H}^{+}$ion, which explains the impact that $\mathrm{pH}$ might have on resistance to aminoglycosides (Fraimow et al. 1991; Eisenberg et al. 1984). According to Moriarty et al. (2007), bactericidal effect of tobramycin against $P$. aeruginosa decreases when the bacterium grows in acidic condition. In addition, the sensitivity to ceftazidime is not influenced by $\mathrm{pH}$. The influence of $\mathrm{pH}$ on acquired resistance to aminoglycoside drugs such as amikacin and neticillin has been examined by Xiong et al. (1996). These authors showed that bactericidal effect of aminoglycoside drugs depended on their concentrations at $\mathrm{pH}$ 7.4. At $\mathrm{pH}$ 6.5 , the bactericidal activity of amikacin and neticillin was very weak when compared to the one observed at $\mathrm{pH} 7.4$. At $\mathrm{pH}$ 5.5, amikacin and neticillin do not have bactericidal effect on $P$. aeruginosa.

\section{Conclusion}

Groundwaters of Douala and Yaoundé towns harbour multi-drug-resistant $P$. aeruginosa strains. The relationship between antimicrobial susceptibility and organic pollution remained weak in these regions. Only the $\mathrm{pH}$ was found to have an impact on the variation of inhibition diameter values of antibiotics. The values of physicochemical parameters showed that environmental conditions leading in groundwaters of Douala and Yaoundé are less stressful for P. aeruginosa. This might explain the weak relationship between abiotic factors and antimicrobial susceptibility.
Acknowledgements The authors thank the authorities of the Laboratory of Microbiology and Environment of Centre Pasteur of Cameroon, those of the University of Yaoundé 1 (Cameroon) and the University Clermont Auvergne (France), for their logistic and material contributions.

Open Access This article is distributed under the terms of the Creative Commons Attribution 4.0 International License (http://creativeco mmons.org/licenses/by/4.0/), which permits unrestricted use, distribution, and reproduction in any medium, provided you give appropriate credit to the original author(s) and the source, provide a link to the Creative Commons license, and indicate if changes were made.

\section{References}

Akoachere J, Kihla T, Omam L, Massalla TN (2013) Assessment of the relationship between bacteriological quality of dug-wells, hygiene behaviour and well characteristics in two cholera endemic localities in Douala, Cameroon. BMC Public Health 13:692. https://doi. org/10.1186/1471-2458-13-692

APHA: American Public Health Association (2012) Standard methods for the examination of water and waste water. APHA 22th Edition, Washington DC

Ateba NS, Ngaba GP, Ebongue CO, Ngassongo RO, Tsiagadigui JG, Behiya G, Nguepi E, Adiogo D (2013) Susceptibility to colistin of multi-resistant Pseudomonas aeruginosa isolated in Douala Laquintinie Hospital, Cameroon. Afr J Pathol Microbiol 2:4. https ://doi.org/10.4303/ajpm/23564

BUCREP: Bureau Central des Recensements et des Etudes de Populations (2010) Livre «Rapport de Présentation»

CA-SFM: Comité de l'Antibiogramme de la Société Française de Microbiologie (2013) Recommandations. SFM edit, Créteil (http://www.sfm-microbiologie.org/). Accessed 23 Juin 2014

Czekalski N, Berthold T, Caucci S, Egli A, Bürgmann H (2012) Increased levels of multiresistant bacteria and resistance genes after wastewater treatment and their dissemination into lake Geneva, Switzerland. Front Microbiol 3:106. https://doi. org/10.3389/fmicb.2012.00106

Drouart F, Vouillamoz JM (2012) Eau-Assainissement-Hygiène pour les populations à risque. Hermann édit., Paris

Eisenberg ES, Mandel J, Kaback HR, Miller MH (1984) Quantitative association between electrical potential across the cytoplasmic membrane and early gentamicin uptake and killing in Staphylococcus aureus. J Bacteriol 157:863-867

Fraimow HS, Greenman JB, Leviton IM, Dougherty TJ, Miller MH (1991) Tobramycin uptake in Escherichia coli is driven by either electrical potential or ATP. J Bacteriol 173:2800-2808

Fuentefria DB, Ferreira AE, Corção G (2011) Antibiotic-resistant Pseudomonas aeruginosa from hospital wastewater and superficial water: are they genetically related? J Environ Manag 92:250255. https://doi.org/10.1016/j.jenvman.2010.09.001

Gaze WH, Zhang L, Abdouslam NA, Hawkey PM, Calvo-Bado L, Royle J, Brown H, Davis S, Kay P, Boxall ABA (2011) Impacts of anthropogenic activity on the ecology of class 1 integrons and integron-associated genes in the environment. ISME J 5:12531261. https://doi.org/10.1038/ismej.2011.15

Ghotaslou R, Behnaz S (2013) Effects of oxygen on in vitro biofilm formation and antimicrobial resistance of Pseudomonas aeruginosa. Pharm Sci 19:96-99

Goto S, Enomoto S (1970) Nalidixic acid cetrimide agar. A new selective plating medium for the selective isolation of 
Pseudomonas aeruginosa. Microbiol Immunol 4:65-70. https:// doi.org/10.1111/j.1348-0421.1970.tb00492.x

Hancock REW, Speert DP (2000) Antibiotic resistance in Pseudomonas aeruginosa: mechanisms and impact on treatment. Drug Resist Updat 3:247-255. https://doi.org/10.1054/drup.2000.0152

Hieng IO (2003) Etude des paramètres géotechniques des sols du Cameroun. Edition CLE, Yaoundé, Cameroun

Holt JG, Krieg NR, Sneath PHA, Staley JT, Williams ST (2000) Bergey's manual of determinative bacteriology. 9th edn. Lippincott Williams and Wikins Publications, Philadelphia

INS: Institut National de la Statistique (2013) Qualité des eaux de surface et souterraines dans la ville de Yaoundé et son impact sanitaire. Publication du Département des Statistiques Démographiques et Sociales de Juin 2013

Johnson L, Mulcahy H, Kanevets U, Shi Y, Lewenza S (2012) Surfacelocalized spermidine protects the Pseudomonas aeruginosa outer membrane from antibiotic treatment and oxidative stress. J Bacteriol 194: 813-826. https://doi.org/10.1128/JB.05230-11

Kamga GH, Michel T, Zacharie S, Jean Marie NN, Calixte DM, Dieudonné A (2015) Caractérisation phénotypique des souches de Pseudomonas aeruginosa isolées dans la ville de Yaoundé (Cameroun). Afr J Pathol Microbiol 4: 4. https://doi.org/10.4303/ ajpm/235908

Macdonald IA, Kuehn MJ (2013) Stress-induced outer membrane vesicle production by Pseudomonas aeruginosa. J Bacteriol 195:2971-2981. https://doi.org/10.1128/JB.02267-12

Macfarlane EL, Kwasnicka A, Hancock RE (2000) Role of Pseudomonas aeruginosa PhoP-phoQ in resistance to antimicrobial cationic peptides and aminoglycosides. Microbiology 146:25432554. https://doi.org/10.1099/00221287-146-10-2543

Mathee K, Narasimhan G, Valdes C, Qiu X, Matewish JM, Koehrsen $M$ et al (2008) Dynamics of Pseudomonas aeruginosa genome evolution. Proc Natl Acad Sci USA 105:3100-3105. https://doi. org/10.1073/pnas.0711982105

McMahon M, Ann S, Jiru X, John E, Moore Ian S, David A (2007) Environmental stress and antibiotic resistance in food-related pathogens. Appl Environ Microbiol 73:211-217. https://doi. org/10.1128/AEM.00578-06

Mérens A, Delacour H, Plésiat P, Cavallo J-D, Jeannot K (2011) Pseudomonas aeruginosa et résistance aux antibiotiques. Revue Francophone des Laboratoires 2011(435):49-62. https://doi. org/10.1016/S1773-035X(11)71102-9

Mérens A, Jault P, Bargues L, Cavallo JD (2013) Infections à Pseudomona aeruginosa. EMC Maladies infectieuses $10: 1-18$. https ://doi.org/10.1016/S1166 8598(12)56974-7

Moriarty TF, Elborn JS, Tunney MM (2007) Effect of pH on the antimicrobial susceptibility of planktonic and biofilm-grown clinical Pseudomonas aeruginosa isolates. Br J Biomed Sci 64:101-104. https://doi.org/10.1080/09674845.2007.11732766
Nguyen D, Joshi-Datar A, Lepine F, Bauerle E, Olakanmi O, Beer K (2011) Active starvation responses mediate antibiotic tolerance in biofilms and nutrient-limited bacteria. Science 334:982-986. https://doi.org/10.1126/science.1211037

Nola M, Njine T, Sikati VF, Djuikom E (2001) Distribution of Pseudomonas aeruginosa and Aeromonas hydrophila in grounwaters in equatorial region of Cameroon and relationships with some chemical parameters of water. Rev Sci Eau 14:35-53

Nougang ME, Nola M, Djuikom E, Noah EOV, Moungang LM, Ateba BH (2011) Abundance of faecal coliforms and pathogenic E. coli strains in groundwater in the coastal zone of Cameroon (Central Africa), and relationships with some abiotic parameters. Cur Res J Biol Sc 3:622-632

Poole K (2012a) Bacterial stress responses as determinants of antimicrobial resistance. J Antimicrob Chemother 67:2069-2089. https ://doi.org/10.1093/jac/dks196

Poole K (2012b) Stress responses as determinants of antimicrobial resistance in gram negative bacteria. Trends Microbiol 20:227234. https://doi.org/10.1016/j.tim.2012.02.004

Rodier J (2009) Analyse de l'eau. Dunod (ed.), 9th edit, Paris

Satoru S, Phan TP (2012) Distribution of quinolones, sulfonamides, tetracyclines in aquatic environment and antibiotic resistance in Indochina. Front Microbiol 3:67-70. https://doi.org/10.3389/ fmicb.2012.00067

Schreiber K, Krieger R, Benkert B, Eschbach M, Arai H, Schobert M, Jahn D (2007) The anaerobic regulatory network required for Pseudomonas aeruginosa nitrate respiration. J Bacteriol 189:4310-4314. https://doi.org/10.1128/JB.00240-07

Stover CK, Pham XQ, Erwin AL, Mizoguchi SD, Warrener P, Hickey MJ et al (2000) Complete genome sequence of Pseudomonas aeruginosa PAO1, an opportunistic pathogen. Nature 406:959-964. https://doi.org/10.1038/35023079

Wood LF, Ohman DE (2009) Use of cell wall stress to characterize $-22(\mathrm{~A} \lg \mathrm{T} / \mathrm{U})$ activation by regulated proteolysis and its regulon in Pseudomonas aeruginosa. Mol Microbiol 72:183-201. https:// doi.org/10.1111/j.1365-2958.2009.06635.x

Xiong YQ, Caillon J, Henri D, Pl Gilles, Denis B (1996) Influence of $\mathrm{pH}$ on adaptive resistance of Pseudomonas aeruginosa to aminoglycosides and their postantibiotic effects. Antimicrob Agents Chemother 40:35-39

Publisher's Note Springer Nature remains neutral with regard to jurisdictional claims in published maps and institutional affiliations. 